\title{
Teaching Video NeuroImages: Hepatic myelopathy
}

\section{An unusual neurologic complication of hepatic encephalopathy}

Vinícius Boaratti Ciarlariello, MD, Marcos Vinícius Tadao Fujino, MD, Marcio Dias de Almeida, MD, PhD, Orlando G.P. Barsottini, MD, PhD, and José Luiz Pedroso, MD, PhD

Neurology ${ }^{\circledR}$ 2019;93:e320-e321. doi:10.1212/WNL.0000000000007782

\section{Correspondence}

Dr. Pedroso

jlpedroso.neuro@gmail.com
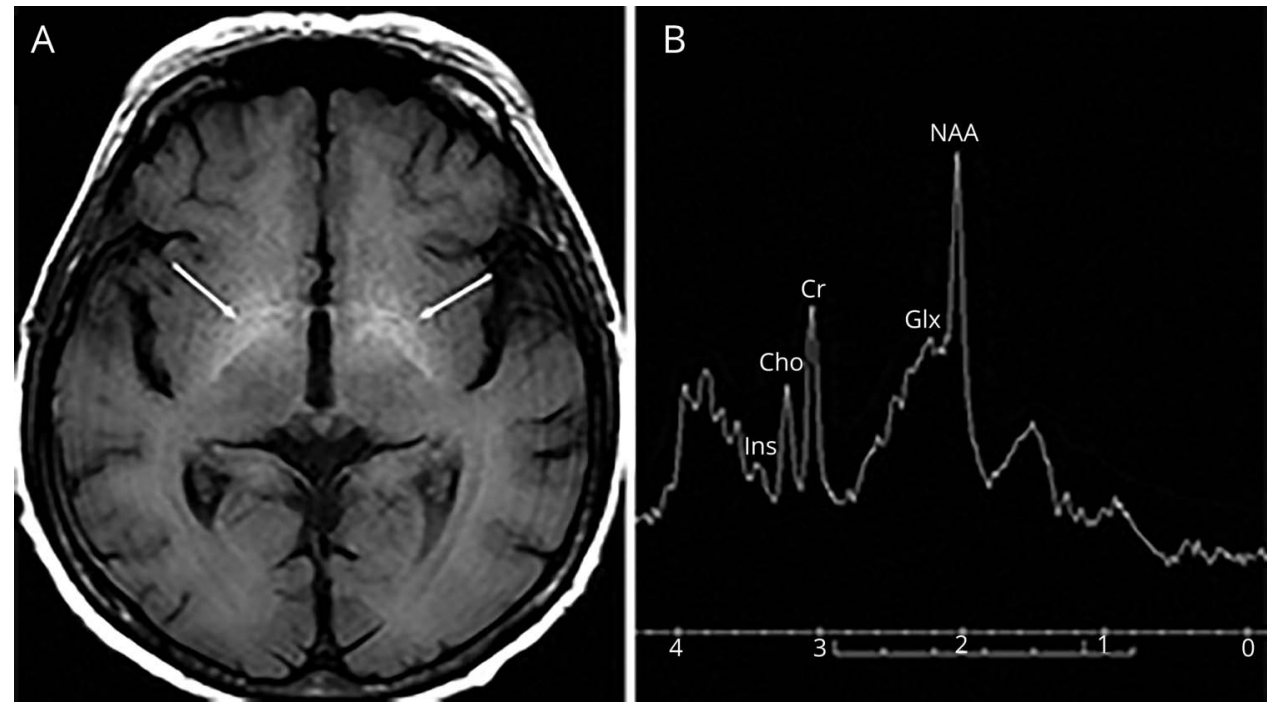

(A) T1-weighted axial brain MRI shows hyperintense signal in internal globus pallidus (manganese deposition due to hepatic encephalopathy [HE]).(B) MRI spectroscopy with water-suppressed proton spectra of a voxel located in normal-appearing parietal white matter shows an increase in glutamine/glutamate signal intensity (Glx, 2.15-2.45 ppm) associated with a decrease in myo-inositol (Ins, $3.45 \mathrm{ppm}$ ) and choline (Cho, 3.2 ppm). N-acetylaspartate (NAA) index has normal signal intensity $(2.0 \mathrm{ppm})$. These findings are typically observed in HE.

A 57-year-old man with alcoholic cirrhosis presented with a 4-year history of hepatic encephalopathy (HE) and progressive gait impairment that worsened during HE (video 1). Examination disclosed spasticity and weakness in lower limbs. Brain MRI showed hyperintense signal in basal ganglia and spectroscopy disclosed increased glutamine/glutamate and decreased myo-inositol (figure). Spine MRI was normal, and other causes were ruled out. Hepatic myelopathy was diagnosed.

Hepatic myelopathy is an unusual complication of liver disease and is characterized by progressive spasticity and lower limbs weakness over the years. ${ }^{1}$ Symptoms usually worsen during HE episodes. Treatment of $\mathrm{HE}$ and liver transplantation may partially improve gait. ${ }^{2}$

\section{Author contributions}

V.B. Ciarlariello: case report project: conception, organization, execution; manuscript: writing of the first draft, review and critique. M.V.T. Fujino: case report project: conception, organization, execution; manuscript: writing of the first draft, review and critique. M.D.d. Almeida: case report project: conception, organization, execution; manuscript: review and critique. O.G.P. Barsottini: case report project: conception, organization, execution; manuscript: review and critique. J.L. Pedroso: case report project: conception, organization, execution; manuscript: review and critique.

\section{MORE ONLINE}

\section{- Video}

$\rightarrow$ Teaching slides

links.lww.com/WNL/

A926

From the Department of Neurology (V.B.C., M.V.T.F., M.D.d.A.), Hospital Israelita Albert Einstein; and Department of Neurology (O.G.P.B., J.L.P.), Ataxia Unit, Universidade Federal de São Paulo, Brazil.

Go to Neurology.org/N for full disclosures. Funding information and disclosures deemed relevant by the authors, if any, are provided at the end of the article. 


\section{Study funding}

No targeted funding reported.

\section{Disclosure}

The authors report no disclosures relevant to the manuscript. Go to Neurology.org/ $\mathrm{N}$ for full disclosures.

\section{References}

1. Utku U, Asil T, Balci K, Ilkay U, Çelik Y. Hepatic myelopathy with spastic paraparesis. Clin Neurol Neurosurg 2005;107:514-516.

2. Yin YH, Ma ZJ, Guan YH, Ren YD, Zhang ZL. Clinical features of hepatic myelopathy in patients with chronic liver disease. Postgrad Med J 2009;85:64-68. 


\section{Neurology}

\section{Teaching Video NeuroImages: Hepatic myelopathy: An unusual neurologic complication of hepatic encephalopathy}

Vinícius Boaratti Ciarlariello, Marcos Vinícius Tadao Fujino, Marcio Dias de Almeida, et al.

Neurology 2019;93;e320-e321

DOI 10.1212/WNL.0000000000007782

\section{This information is current as of July 15, 2019}

\section{Updated Information \& Services}

References

Citations

Subspecialty Collections

Permissions \& Licensing

Reprints including high resolution figures, can be found at: http://n.neurology.org/content/93/3/e320.full

This article cites 2 articles, 1 of which you can access for free at: http://n.neurology.org/content/93/3/e320.full\#ref-list-1

This article has been cited by 1 HighWire-hosted articles: http://n.neurology.org/content/93/3/e320.full\#\#otherarticles

This article, along with others on similar topics, appears in the following collection(s):

All Medical/Systemic disease

http://n.neurology.org/cgi/collection/all_medical_systemic_disease All Spinal Cord

http://n.neurology.org/cgi/collection/all_spinal_cord

Gait disorders/ataxia

http://n.neurology.org/cgi/collection/gait_disorders_ataxia MRI

http://n.neurology.org/cgi/collection/mri

Spastic paraplegia

http://n.neurology.org/cgi/collection/spastic_paraplegia

Information about reproducing this article in parts (figures,tables) or in its entirety can be found online at:

http://www.neurology.org/about/about_the_journal\#permissions

Information about ordering reprints can be found online:

http://n.neurology.org/subscribers/advertise

Neurology ${ }^{\circledR}$ is the official journal of the American Academy of Neurology. Published continuously since 1951, it is now a weekly with 48 issues per year. Copyright @ 2019 American Academy of Neurology. All rights reserved. Print ISSN: 0028-3878. Online ISSN: 1526-632X.

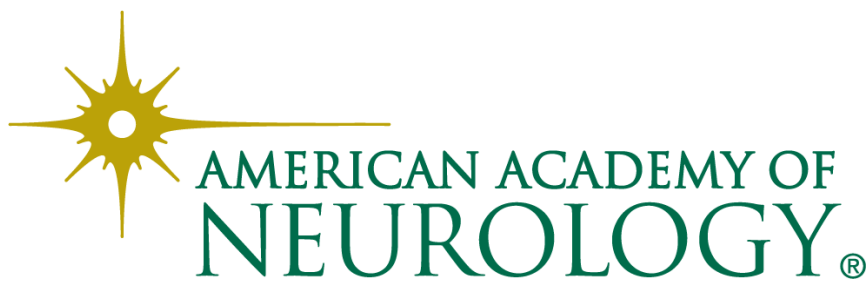

